\title{
Comment on editorial
}

\section{RELIGIOUS DENOMINATIONS VS ETHICAL MODELS IN THE BEGINNING OF LIFE}

\author{
Arif Hossain, \\ Vice President \\ Bangladesh Bioethics Society. \\ Email:ykhsmh@yahoo.com
}

\begin{abstract}
An article was published at editorial of BJB in 2012 vol. 3 issue 1, page 3 entitled" Challenge of 21 st Century to Integrate the Reproductive Technologies Concerning the Beginning of Human Life" written by Associate Editor of BJB. I would like to comment on article that the religions those have holy book from God have almost the same notion regarding the beginning of life. They are involved with biblical account of the creation of human and prefixed notion on procreation and families. From a bioethical point of view, religions seem to favor "deontological" models. It may hinder the proper ethical incorporation of reproductive technologies. Stewardship or divine providence leads to a fixed creational view, pessimist as basic attitude and dependence. On the other hand, other distinguished ethical models (consequentialism or utilitarianism) are "creativity", e.g. models of responsibility (personalism), models of caring (care ethics) etc. These models are anthropo-centric, optimistic, evolving creation (Created Co-Creator) and have open future. Therefore, it is crucial to understand how 21 st century will integrate the new technologies concerning the beginning of human life.
\end{abstract}

DISCUSSION: All the religions have almost the same notion on beginning of life. According to Hinduism human animating spirit is present from fertilization. So the embryo is given the status of person throughout pregnancy. Hindu concern with moral attitudes toward research on the preembryo is exploitation of the vulnerable. Islamic Code of Medical Ethics gives the moral status of the human embryo from the current fixations of movement (14th day after fertilization). According to Islamic Jurisprudence (Shari'a Law) procreation and parenting relationships are lawful between valid spouses because of designated role-responsibilities. Use of third party gametes for reproduction violates precepts concerning legitimacy, lineage, and inheritance. Roman Catholic bans all types of reproductive technology. In school of Protestant accept the expansion of human freedoms and control over human reproduction. 
The themes of theological bioethics are "deontological" models. They are involved with biblical account of the creation of humans and prefixed notion on procreation and families. They consider human dominion over nature as playing God. Sometimes, it violates the human dignity (contrary to Declaration on Human Rights and Biomedicine). In addition, there is a challenge of pluralism for religious denominations. The basic respect is that everyone's religious belief. Stewardship or divine providence leads to a fixed creational view, theo-centric, pessimist as basic attitude and dependence. It may hinder the proper ethical incorporation of reproductive technologies.

On the other hand, other distinguished ethical models e.g. consequentialism or utilitarianism (actions are right or wrong according to the balance of their good and bad consequences), models of responsibility (personalism-act is good if the gain aimed at outweighs the damage incurred), models of caring (care ethics-relationship-based accounts: caring in these accounts refers to care for, emotional commitment to, and willingness to act on behalf of persons with whom one has a significant relationship) etc are "creative" model. These models are anthropocentric, optimistic, evolving creation (Created Co-Creator) and have open future. Some examples are given below.

In vitro fertilisation (IVF) or test tube baby is a process by which an egg is fertilized by sperm outside the body and latter transferred to the womb of mother for further development of baby. Since the fallopian tube is the only place in the female body where normal fertilization can occur, if both tubes become blocked, pregnancy becomes difficult or impossible. IVF is a major treatment for infertility when other methods of assisted reproductive technology have failed. IVF is designed for the treatment of severe tubal disease, Infections, inflammations, endometriosis and other conditions may cause irreparable damage to the fallopian tubes. IVF allows for successful fertilization outside the fallopian tube, thus bypassing the problem area. Another common indication for IVF is low sperm counts. In recent years a process has been developed where a single sperm can be injected into an egg to cause fertilization in the laboratory, a procedure called intracytoplasmic sperm injection (ICSI).

Surrogacy: If the embryo is transferred to the womb of other lady is called surrogacy. Women, with congenital absence of the uterus or who have had a hysterectomy for carcinoma or haemorrhage, but who all still have functioning ovaries or who have suffered repeated miscarriages and for whom the chance of ever carrying a baby to term is remote, women who repeatedly fail to implant normal healthy embryo in her uterus and who have certain medical condition, such as cancer, heart or renal disease which might threaten the life of a woman are considered to be suitable candidates for this type of surrogacy. When a woman/man is incapable of producing ova/sperm as a result of disease e.g. cancer, injury, congenital absent of gamet or normal aging, a donor ovum/sperm may be fertilized in vitro and implanted in her uterus and she 
then gestates the baby to term. The couple may choose this type of surrogacy with the hope that the kid will be at least half-related to them.

Cloning is the process of producing similar populations of genetically identical individuals that occurs in nature. Therapeutic cloning is achieved by creating embryonic stem cells in the hopes of treating diseases such as diabetes and Alzheimer's, cancer, cosmetic surgery. Dolly, a FinnDorset ewe, was the first mammal to have been successfully cloned from an adult cell. If the cloned human is born, beginning of life human will be redefined.

Pre-Implantation Genetic Diagnosis (PGD) is essentially who have been confronted with serious genetic risks in their family and want to prevent further problems in the future. It offers concrete problem solving for couples confronted with serious risks of genetic abnormalities for their children.

From above mentioned examples, it is understandable that incorporation of these reproductive technology needs ethical models e.g. utilitarianism or personalism.

CONCLUSION: A careful balancing of values and disvalues in concrete clinical cases can help to integrate ethically the possibilities of IVF, surrogacy, cloning and PGD in such a way that this integration promotes the humanly possible. The linkage with ethical models is in many cases more important than the linkage with religious denominations. So, it is crucial to understand how 21 st century will integrate the new technologies concerning the beginning of life. Moral sensitivities are essential concerning a medical reality.

\section{REFERENCES:}

Brinsden RP. Gestational surrogacy. Human Reproduction Update 2003. 9;5:483-91.

Beauchamp TI. \& Childress JF. Principles of Biomedical Ethics. Fourth Edition, Oxford, Oxford University Press, 1994.

Böckle F. Fundamental Moral Theology. Dublin, Gill and Macmillan, 1980.

Cloning. http://en.wikipedia.org/wiki/Cloning (access on 22 August 2012)

Human cloning. http://en.wikipedia.org/wiki/Human cloning (access on 22 August 2012) 
In Vitro Fertilization. http://en.wikipedia.org/wiki/In vitro fertilisation (access on 22 August 2012)

Lasker S. Challenge of 21 st Century to Integrate the Reproductive Technologies Concerning the Beginning of Human Life. BJB 2012; 3 (1):3.

Schotsmans P. Responsible Involvement and Conscientious Freedom: A Relational Approach to Medical Ethics' in J. SELLING (Ed.), Personalist Morals. Leuven, University Press, 1988, p. 167184.

Schotsmans P. Personalism in Medical Ethics. Ethical Perspectives 6 (1999)1, p. 10-20

CONFLICT OF INTEREST: no conflict of interest 